\title{
Corneal transplantation in the United Kingdom and Republic of Ireland
}

\author{
A Vail, S M Gore, B A Bradley, D L Easty, C A Rogers on behalf of collaborating surgeons
}

\section{University of Bristol Department of Transplantation Sciences, Southmead Hospital, Bristol A Vail \\ B A Bradley}

MRC Biostatistics Unit, Institute of Public Health, Robinson Way, Cambridge S M Gore

University of Bristol Department of Ophthalmology, Bristol Eye Hospital, Bristol D L Easty

UK Transplant Support Southmead Road, Bristo C A Rogers

Correspondence to: Professor B A Bradley, Director, Department of Transplantation Sciences, Medical School Unit, Southmead, Bristol BS10 5NB.

Accepted for publication 18 May 1993 Service Authority,

\begin{abstract}
The Corneal Transplant Follow up Study has registered 4560 corneal grafts performed in the United Kingdom and Republic of Ireland from July 1987 to June 1991. Rates of reported grafts doubled during that time. This increase was greater for surgeons and regions reporting fewer grafts, but was consistent across patient factors. Eleven of 428 consultants were responsible for over $25 \%$ of grafts, and their patients' characteristics differed significantly from others. Overall, reasons for grafting were visual only $(77 \%)$, visual and other $(16 \%)$, and non-visual (7\%). Most frequent diagnoses were endothelial failure (38\%), inflammation $(26 \%)$, and keratoconus (20\%). Age ranged from 2 months to 97 years, and differed markedly with diagnosis. Eighteen per cent of transplants were regrafts, and $40 \%$ were vascularised preoperatively.
\end{abstract}

(Br F Ophthalmol 1993; 77: 650-656)

The Corneal Transplant Service (CTS) began a national cornea redistribution programme in 1983, under the auspices of the then United Kingdom Transplant Services (UKTS). ${ }^{1}$ Little was known at the time concerning numbers of grafts performed, numbers of surgeons operating, national success rates, or reasons for graft failure.

Practices differ widely between centres, so that one centre's experience may bear little relevance to another's. Despite clear interdepen-

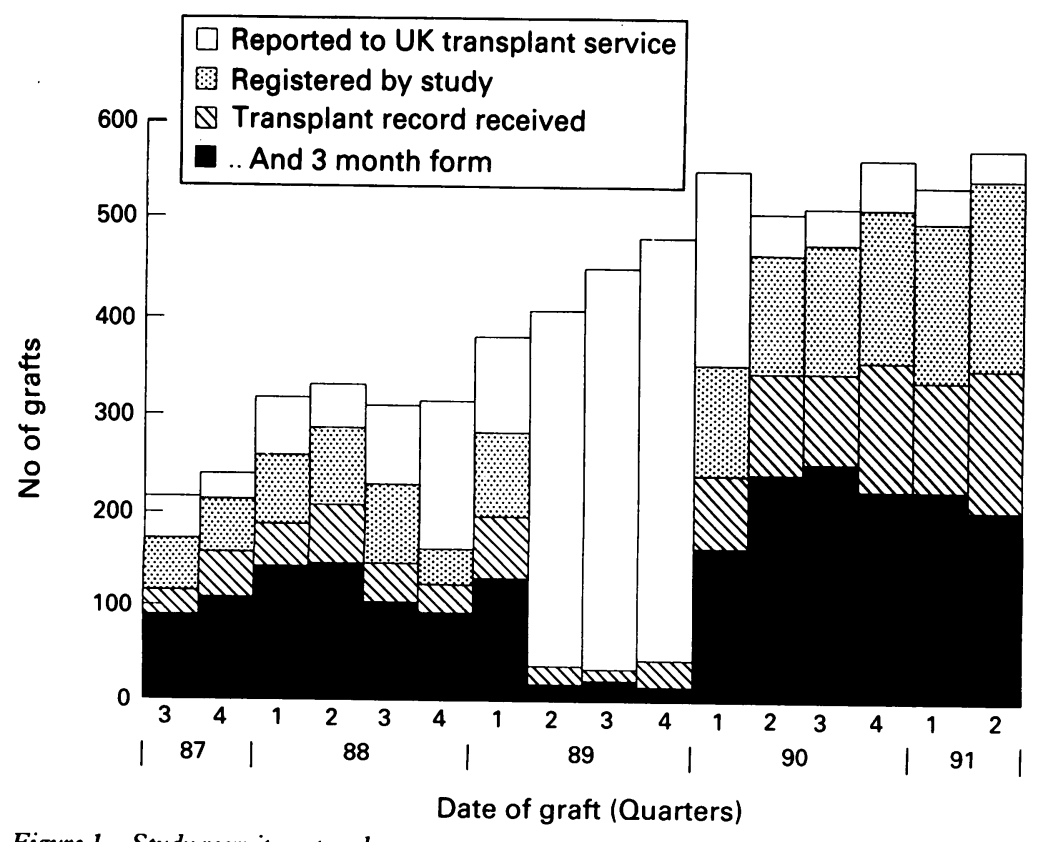

Figure 1 Study recruitment and response rates. dence of reported risk factors, unifactorial analyses of graft survival remain comparatively common. Moreover, visual performance, although often of primary concern, is seldom analysed.

The CTS Eye Bank, first established at Bristol Eye Hospital in 1986, introduced storage of donor tissue in organ culture at $34^{\circ} \mathrm{C}$ to the United Kingdom. ${ }^{2}$ Increasing 'shelf life' from 4 to 30 days provided opportunities to investigate storage factors. In 1987, the Corneal Transplant Follow up Study (CTFS) set out to evaluate donor, recipient, histocompatibility, and operative factors in relation to both graft survival and visual performance of functioning grafts. Here we examine only broad characteristics of corneal recipients, in terms of 'who? where? when? why?': who received a corneal graft, where and when was the operation performed, and why was it required? Analysis of more detailed descriptors, of clinical condition, surgical technique, and donor tissue is left to subsequent papers.

\section{Methods}

Planning, design, and organisation involved UKTS, CTS, and the MRC Biostatistics Unit. A statistician was based at UKTS to establish a study database with links to the national transplant database, and to undertake the day to day running.

Forms were prepared for completion at the time of transplant, and at 3 and 12 months postoperatively. Questions covered a wide range of relevant conditions and outcomes. Transplant record forms asked questions relating to patient medical history, preoperative clinical record, and operative details. Three and 12 month follow up forms covered graft status, rejection episodes, and clinical record, including visual acuity and refractive error for the grafted eye. In addition, 3 month follow up included a history of postoperative complications.

To encourage participation, forms were designed to work as an integral part of patient notes, and bright colours were chosen to aid recognition of misplaced forms. Data entry by non-clinicians obliged use of numerical coding and avoidance of free text wherever possible.

A manual, detailing CTFS objectives, was sent to consultant ophthalmic surgeons, who were invited to participate by reporting all transplants undertaken. Additional surgeons were coopted when performing grafts with tissue that was either organ cultured or HLA typed.

CTFS registered its first corneal transplant in July 1987. Originally planned as a 3 year project, a 10 month break from April 1989 led to continuation of recruitment through to June 
*SE Thames (471) W Midlands (575)

*N Western (568)

*S Western (382)

*E Anglia (184)

Northern (304)

Yorkshire (321)

Mersey (197)

Trent (327)

Oxford (135)

NW Thames (224)

SW Thames (150)

Wessex (184)

*NE Thames (90)

Isle of Man (1)

Wales (147)

Scotland (175)

$N$ Ireland (49)

Rep Ireland (76)

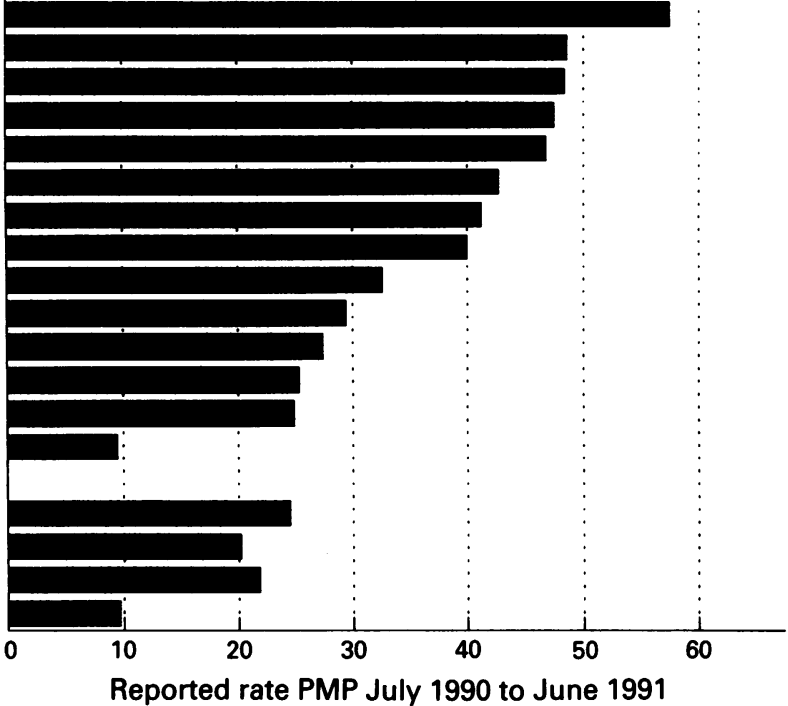

Figure 2 Regional transplant rates. pmp=per million population. ${ }^{\star}$ Regions with eye banks contributing to Corneal Transplant Service Network.

1991. A part-time clerical officer was added to the team in 1990 to cope with increasing numbers of reported grafts.

The CTFS database was constructed and maintained using the FORTRAN and DATATRIEVE languages. Analyses were conducted using BMDP statistical software.

\section{Results}

RESPONSE

A total of 4560 corneal grafts were registered. Figure 1 shows a quarterly breakdown of recruitment, with UKTS registration figures for comparison. Decline between April 1989 and February 1990 was caused by a temporary lull pending new staff appointments.

Complete or partial information was returned on 3213 transplant record forms. In subsequent tables, totals less than 3213 omit data missing for
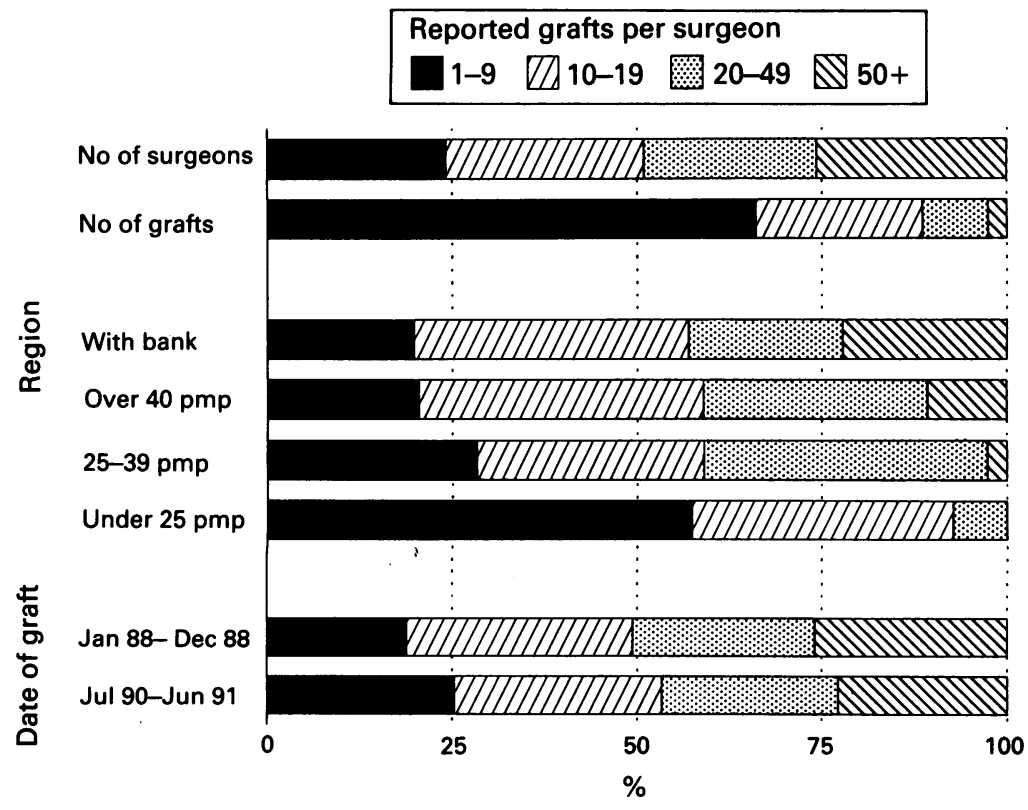

Figure 3 Surgeon, region, and period classification according to reported grafts per surgeon ( $p m p=$ per million population).
Table 1 Development of regional transplant activity

\begin{tabular}{lllr}
\hline & \multicolumn{2}{l}{ Date of transplant } & \\
\cline { 2 - 3 } Region & $\begin{array}{l}\text { fan 1988 } \\
\text { to Dec 1988 }\end{array}$ & $\begin{array}{l}\text { Fuly 1990 } \\
\text { to fune 1991 }\end{array}$ & Total \\
\hline With bank & 340 & 652 & 992 \\
Over 40 pmp & 292 & 630 & 922 \\
25-39 pmp & 207 & 469 & 676 \\
Under 25 pmp & 51 & 207 & 258 \\
Total & 890 & 1958 & 2848 \\
\hline
\end{tabular}

$\mathrm{pmp}=$ per million population.

specific questions. Despite a twofold increase in numbers of registered grafts over the course of CTFS, return rates for transplant record forms remained consistent, at around $70 \%$ throughout.

REGIONAL VARIATION

In all, 216 centres were involved. Figure 2 gives numbers of reported grafts by region. Rates per million population (pmp) are calculated using transplants during the last 12 months of CTFS, to avoid bias caused by staffing levels. Reported rates in England ranged from 25 to $57.5 \mathrm{pmp}$, and were highest in regional health authorities with eye banks contributing to the CTS network (SE Thames, North Western, South Western, and East Anglia). Exceptions were NE Thames, where partial collaboration with CTFS caused a false low of $9.5 \mathrm{pmp}$, and West Midlands, with a rate of 49 pmp but no eye bank. Centres in Wales (24.5 pmp), Scotland (20.2 pmp), and Northern Ireland $(21.8 \mathrm{pmp})$ reported comparatively few grafts. Figures for the Republic of Ireland cover only corneas supplied via UKTS, and are resultingly low.

Table 1 demonstrates how regional patterns have developed during CTFS. Regions with eye banks form one group, and the remainder are categorised by recent report rate (see Fig 2). NE Thames and the Republic of Ireland are excluded for reasons given above. Figures for the last 12 months of CTFS (July 1990 to June 1991) were compared with those for 1988 , to avoid possible 'lead in' differences during the first 6 months of study. During CTFS reports more than doubled. Increases were greater for regions with lower report rates $\left(\chi_{3}^{2}=20.3, \mathrm{p}<0.001\right)$ : up from 340 to 652 reports from eye bank regions, and from 51 to 207 reports from regions with lowest recent rates.

SURGEON VARIATION

A total of 428 consultants each registered between one and 221 grafts. Of these, at least one CTFS form was returned by 390 (91\%), who are listed in the appendix. Figure 3 shows variation in

Table 2 Distribution of reasons for corneal graft

\begin{tabular}{lrr}
\hline Reasons for graft & Total & $(\%)$ \\
\hline Visual only & 2440 & $(77 \cdot 0)$ \\
Therapeutic only & 180 & $(5 \cdot 7)$ \\
Cosmetic only & 18 & $(0 \cdot 6)$ \\
Visual and therapeutic & 285 & $(9 \cdot 0)$ \\
Visual and cosmetic & 201 & $(6 \cdot 3)$ \\
Therapeutic and cosmetic & 9 & $(0 \cdot 3)$ \\
Visual, therapeutic and cosmetic & 36 & $(1 \cdot 1)$ \\
Total grafts with reasons recorded & 3169 & $(100 \%)$ \\
\hline
\end{tabular}

*Includes combinations of: actual perforation (76); severe infection (51); threatened perforation (44); others (41) 




Figure 4 Reasons for grafting by surgeon group and region ( $p m p=$ per million population).

numbers of grafts reported per surgeon. Nine or fewer grafts were reported by 283 surgeons $(66 \%)$, accounting for 1012 grafts $(22 \%)$. At the other extreme, 11 surgeons each reported in excess of $50 \mathrm{grafts}$, and were collectively responsible for over $25 \%$ (1168) of the total. As might be expected, the distribution of grafts per surgeon varies greatly over regions $\left(\chi_{9}^{2}=1378\right.$, $\mathrm{p}<0.001)$. Highest reporting surgeons are generally located in regions with eye banks or high report rates. Activity levels of these surgeons, being initially higher, increased less over time $\left(\chi_{3}^{2}=16 \cdot 1, p=0 \cdot 001\right)$.

\section{REASONS FOR GRAFTING}

Over $75 \%(2440 / 3169)$ of corneal grafts were performed for visual reasons alone; $180(5 \cdot 7 \%)$ were purely therapeutic, for conditions such as severe infection, pain relief, and threatened or actual perforation. Visual and therapeutic reasons together were cited for a further 321 $(10 \cdot 1 \%)$ cases. Only $264(8 \cdot 3 \%)$ included cosmetic reasons, of which all but $18(0.6 \%)$ were also visual or therapeutic (Table 2 ).

Reasons for grafting differed markedly between surgeons and regions (Fig 4). Highest reporting surgeons transplanted more for purely visual, and less for other reasons $\left(\chi_{6}^{2}=34 \cdot 9\right.$, $\mathrm{p}<0.001$ ). Conversely, surgeons outside England (regional rate below $25 \mathrm{pmp}$ ) were less likely to transplant for purely visual reasons $\left(\chi_{6}^{2}=19 \cdot 8, p=0.003\right)$. There was no evidence of a changing pattern over time $\left(\chi_{2}^{2}=4 \cdot 1\right.$, $\mathrm{p}=\mathbf{0} \cdot 13$ ).

DIAGNOSIS

Diagnosis of original corneal disease was recorded in full. Additionally, clinicians allocated the diagnosis to one of 23 codes. For analysis purposes, this list was extended to incorporate uncoded text. Numbers of recipients in each category are shown in Table 3 . Of 3184 reported diagnoses, endothelial failure was most common with 1217 cases (38\%). Inflammation, typically herpes simplex, herpes zoster, bacterial, or interstitial keratitis, accounted for a further 833 cases (26\%), and $634(20 \%)$ patients had keratoconus.

Age and sex distributions of recipients were analysed in each main diagnostic category (Fig 5). Age ranged from 2 months (diffuse corneal opacity of uncertain aetiology) to 97 years (secondary endothelial failure). Males accounted for two thirds of keratoconus patients, whose average age was 32 years, less.than half that of patients with endothelial failure. The latter were predominantly female (58\%). The greatest sex imbalance was among trauma patients, with 119 $(80 \%)$ males.

Diagnosis and reasons for grafting were strongly associated $\left(\chi_{14}^{2}=312, \quad \mathrm{p}<0.001\right)$. Over $90 \%$ of cases with keratoconus, stromal dystrophy, and primary endothelial failure were transplanted for visual reasons alone. Secondary endothelial failure is often associated with bullous keratopathy, and inflammation and trauma diagnoses with other therapeutic and cosmetic indications (Fig 6). There were also differences between surgeons. Those reporting more than 50 transplants saw fewer endothelial failure cases, and more uncommon diagnoses $\left(\chi_{21}^{2}=41 \cdot 5\right.$, $\mathrm{p}=0.005)$. Less clear were differences between regions $\left(\chi_{21}^{2}=34.9, p=0.03\right)$ and changes over time $\left(\chi_{7}^{2}=12 \cdot 5, \mathrm{p}=0.09\right)$.

PREVIOUS CORNEAL TRANSPLANTATION

Previous transplantation in either eye may increase recipient susceptibility to rejection. A total of 576 of 3179 cases (18\%) were known to be regrafts, in 489 of 3168 cases (15\%) the other eye had been grafted, and 910 of 3134 cases (29\%) had received a previous graft in one or other eye (Table 4). Numbers of previous transplants in the operated eye differed significantly $(\mathrm{p}<0.001)$ by diagnosis $\left(\chi_{7}^{2}=174\right)$, by surgeon

Table 3 Distribution of diagnoses

\begin{tabular}{|c|c|c|c|}
\hline \multicolumn{2}{|l|}{ Diagnosis of original corneal disease } & \multirow{3}{*}{$\begin{array}{r}\text { Total } \\
634 \\
407\end{array}$} & \multirow{3}{*}{$\frac{(\%)}{(19 \cdot 9)}$} \\
\hline Keratoconus & & & \\
\hline Primary endothelial failure & & & \\
\hline $\begin{array}{l}\text { Fuchs' dystrophy } \\
\text { congenital or juvenile }\end{array}$ & $\begin{array}{r}363 \\
44\end{array}$ & 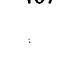 & \\
\hline Secondary endothelial failure & & 804 & $(25 \cdot 3)$ \\
\hline $\begin{array}{l}\text { pseudophakic } \\
\text { aphakic } \\
\text { other }\end{array}$ & $\begin{array}{l}481 \\
221 \\
102\end{array}$ & & \\
\hline Herpes simplex keratitis & & 338 & $(10 \cdot 6)$ \\
\hline $\begin{array}{l}\text { chronic } \\
\text { acute }\end{array}$ & $\begin{array}{r}288 \\
50\end{array}$ & & \\
\hline Other inflammation & & 495 & $(15 \cdot 5)$ \\
\hline $\begin{array}{l}\text { chronic } \\
\text { acute } \\
\text { unspecified }\end{array}$ & $\begin{array}{r}355 \\
112 \\
28\end{array}$ & & \\
\hline Stromal dystrophy & & 151 & $(4 \cdot 7)$ \\
\hline lattice & 62 & & \\
\hline granular & 43 & & \\
\hline macular & 37 & & \\
\hline $\begin{array}{l}\text { unspecified } \\
\text { Trauma }\end{array}$ & 9 & 148 & $(4 \cdot 6)$ \\
\hline $\begin{array}{l}\text { Trauma } \\
\text { mechanical }\end{array}$ & 102 & 148 & $(4 \cdot 6)$ \\
\hline $\begin{array}{l}\text { chemical (alkaline) } \\
\text { chemical (other) }\end{array}$ & $\begin{array}{r}28 \\
18\end{array}$ & & \\
\hline Other diagnoses & & 207 & $(6 \cdot 5)$ \\
\hline congenital malformation & 63 & & \\
\hline $\begin{array}{l}\text { epithelial degeneration } \\
\text { contact lens related }\end{array}$ & $\begin{array}{l}31 \\
14\end{array}$ & & \\
\hline $\begin{array}{l}\text { contact lens related } \\
\text { unspecified endothelial failure }\end{array}$ & $\begin{array}{r}14 \\
6\end{array}$ & & . \\
\hline $\begin{array}{l}\text { unspecified endothelial failure } \\
\text { miscellaneous }\end{array}$ & 35 & & \\
\hline aetiology uncertain & 58 & & \\
\hline Total grafts with diagnoses recorded & & 3184 & $(100 \%)$ \\
\hline
\end{tabular}


Primary endothelial failure (407 cases)

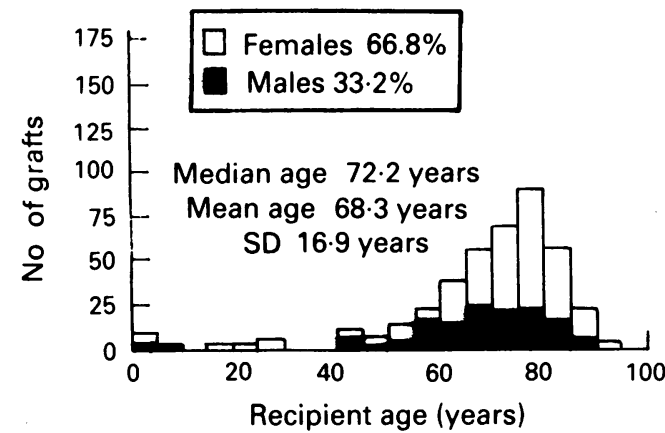

Herpes simplex keratitis

(338 cases)

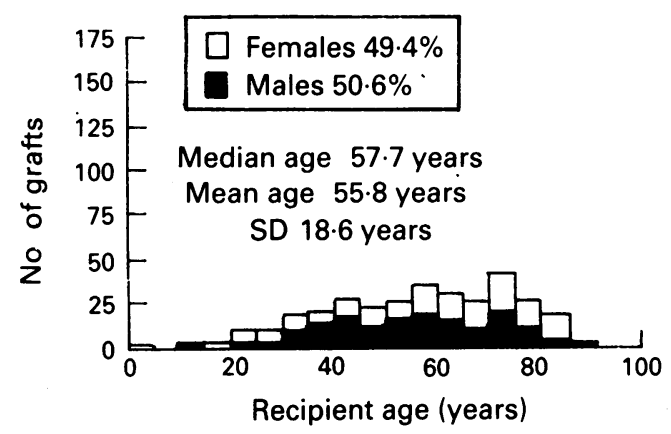

Keratoconus (634 cases)

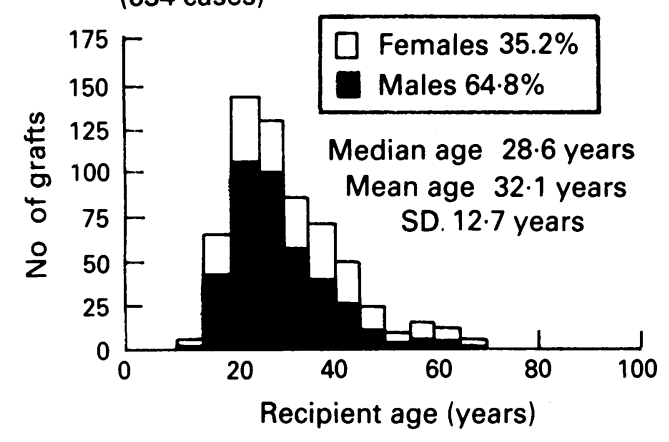

Trauma

(148 cases)



Figure 5 Recipient age and sex by diagnosis.

$\left(\chi_{9}^{2}=67 \cdot 8\right)$, and by region $\left(\chi_{9}^{2}=44 \cdot 3\right)$ (Fig 7). Respectively, regrafts were most common for trauma cases $(49 / 146,34 \%)$, surgeons reporting most grafts $(234 / 955,25 \%)$, and regions with eye banks $(261 / 1252,21 \%)$. Surprisingly, there was not such a clear difference by reasons for grafting $\left(\chi_{6}^{2}=12 \cdot 1, p=0 \cdot 06\right)$.

Previous transplants in the other eye were more common for bilateral conditions
Secondary endothelial failure

(804 cases)

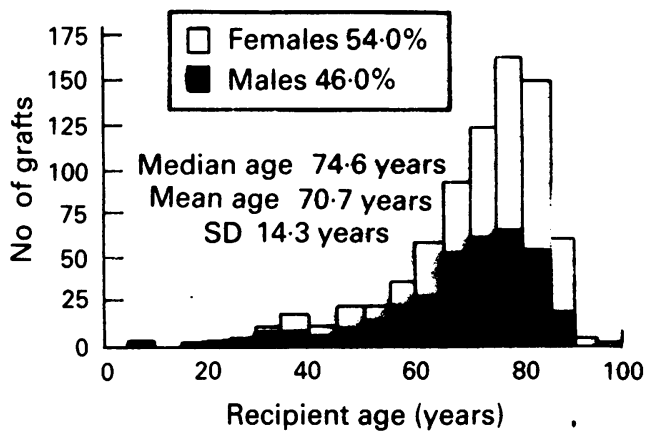

Other inflammation

(495 cases)



Stromal dystrophy

(151 cases)

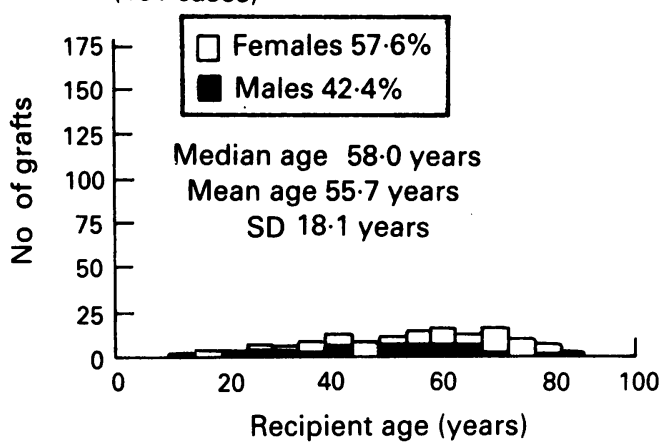

Other diagnoses

(207 cases)

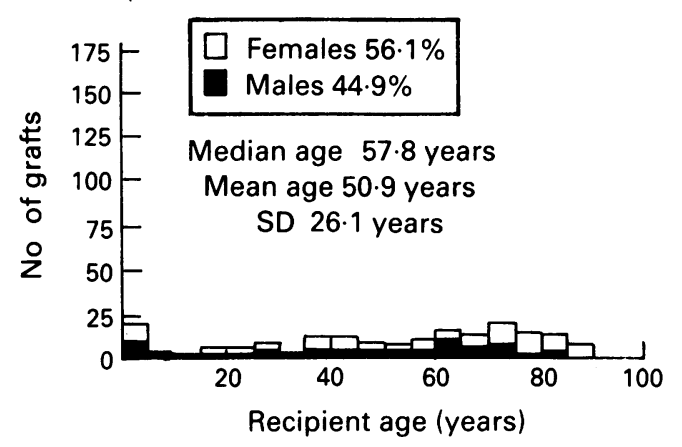

$\left(\chi_{7}^{2}=282, \mathrm{p}<0.001\right)$ (Fig 8). In half $(73 / 150)$ the stromal dystrophy, one quarter $(101 / 396)$ of primary endothelial failure, and one in five $(129 / 630)$ keratoconus patients, the other eye had been grafted. These conditions were also those for which grafting was seldom therapeutic or cosmetic. This is reflected in association $\left(\chi_{2}^{2}=48.4, \quad p<0.001\right) \quad$ with purely visual reasons for grafting. Differences by surgeon 

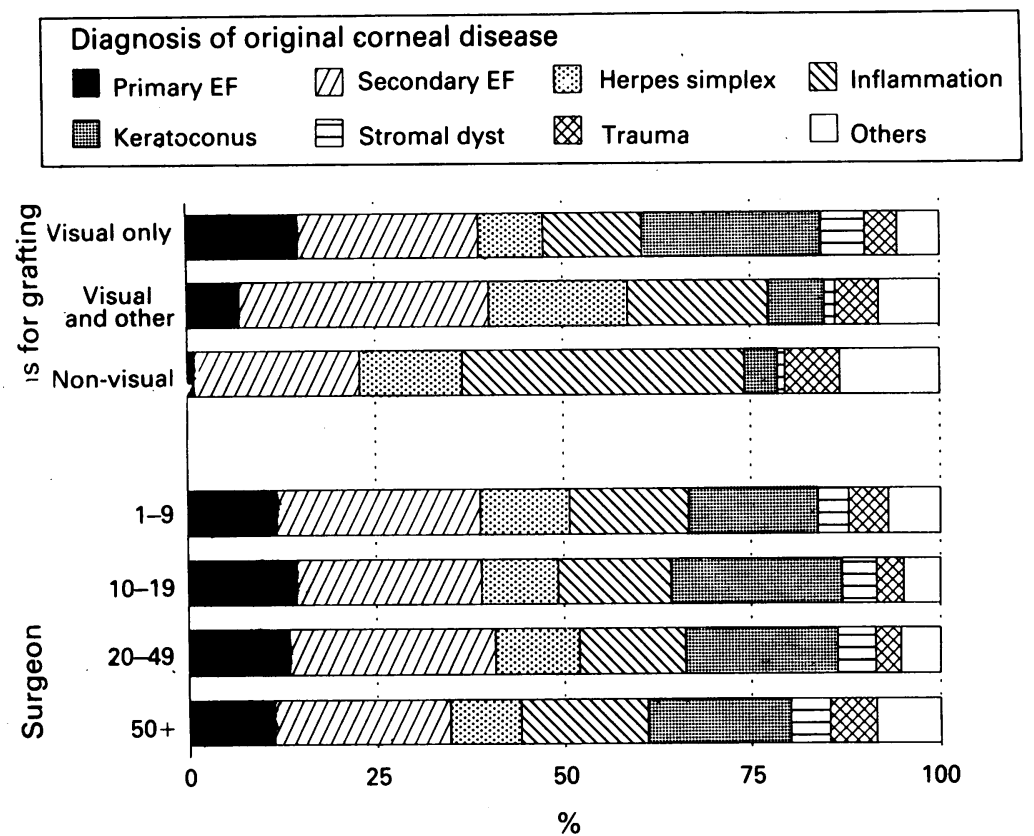

Figure 6 Diagnosis by reasons for grafting and surgeon group. $E F=$ endothelial failure; Dyst $=$ dystrophy.

\section{Previous grafts in operated eye None $\mathbb{Z}$ One $\square$ Two More}

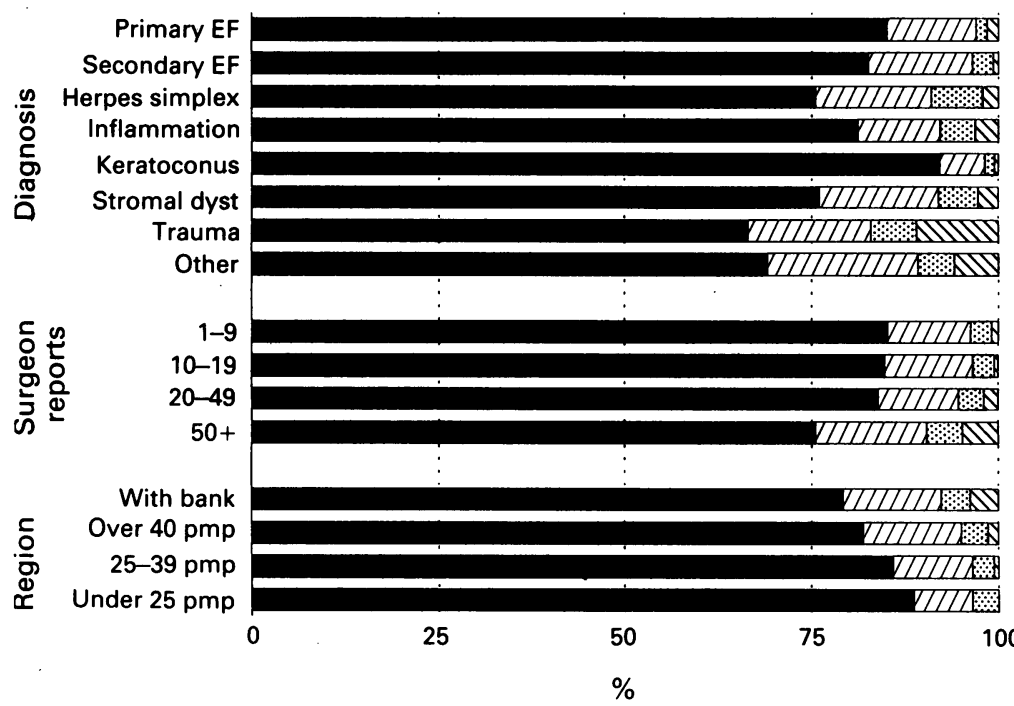

Figure 7 Previous grafts by diagnosis, surgeon group and region. $E F=$ endothelial failure; Dyst $=$ dystrophy, $p m p=$ per million population.

Table 4 Previous corneal grafts in each eye

\begin{tabular}{llrr}
\hline \multirow{2}{*}{$\begin{array}{l}\text { Previous grafts } \\
\text { in operated eye }\end{array}$} & \multicolumn{2}{l}{ Other eye grafted? } & \\
\cline { 2 - 3 } & No & Yes & Total \\
\hline None & 2224 & 346 & 2570 \\
One & 291 & 95 & 386 \\
Two & 86 & 24 & 110 \\
More & 45 & 23 & 68 \\
Total & 2646 & 488 & 3134 \\
\hline
\end{tabular}

Table 5 Preoperative vascularisation (quadrants)

\begin{tabular}{|c|c|c|c|c|c|c|}
\hline \multirow{2}{*}{$\begin{array}{l}\text { Deep } \\
\text { vascularisation }\end{array}$} & \multicolumn{5}{|c|}{ Superficial vascularisation } & \multirow[b]{2}{*}{ Total } \\
\hline & None & One & $T w o$ & Three & Four & \\
\hline None & 1924 & 202 & 161 & 40 & 111 & 2438 \\
\hline One & 39 & 164 & 47 & 16 & 15 & 281 \\
\hline Two & 26 & 7 & 106 & 23 & 23 & 185 \\
\hline Three & $\begin{array}{l}10 \\
30\end{array}$ & 3 & $\begin{array}{l}6 \\
4\end{array}$ & 30 & 16 & $\begin{array}{r}65 \\
219\end{array}$ \\
\hline $\begin{array}{l}\text { Total } \\
\text { Tota }\end{array}$ & 2029 & 382 & 324 & 109 & 344 & 3188 \\
\hline
\end{tabular}

$\left(\chi_{3}^{2}=10.5, \quad \mathrm{p}=0.02\right)$ and by region $\left(\chi_{3}^{2}=\right.$ $10 \cdot 1, \mathrm{p}=0.02$ ) were less clear, and for neither operated eye $\left(\chi_{3}^{2}=5 \cdot 4, p=0 \cdot 15\right)$ nor other eye $\left(\chi_{1}^{2}=0.0, p=0.94\right)$ were changes over time in evidence.

\section{VASCULARISATION}

Degree of vascularisation, measured in numbers of quadrants with blood vessels growing across the cornea, may have a major influence on graft outcome. Only $60 \%$ (1924/3188) of recipients had neither deep nor superficial vascularisation and of the remainder only $131(10 \%)$ had more deep than superficial vascularisation (Table 5). The two were strongly associated $\left(\chi_{16}^{2}=2957\right.$, $\mathrm{p}<0.001)$. As results were similar, associations ( $p<0.001$ in all cases) of only the more common, superficial vascularisation with other factors are reported below.

Superficial vascularisation was less common $\left(\chi_{4}^{2}=19 \cdot 2\right)$ when the other eye had previously been grafted, and more common $\left(\chi_{12}^{2}=232\right)$ in regrafts (Fig 9). This paradox is perhaps explained by strong relations of vascularisation with reasons for grafting $\left(\chi_{8}^{2}=145\right)$ and with diagnosis $\left(\chi_{28}^{2}=588\right)$. Few patients with keratoconus, stromal dystrophy, or primary endothelial failure, conditions with high rates of previous transplants in the other eye, were also vascularised. Similarly, recipients with diagnoses of inflammation or trauma, often with cosmetic or therapeutic reasons for grafting, suffered high rates of vascularisation. There was little difference by surgeon categories $\left(\chi_{12}^{2}=17 \cdot 1\right.$, $\mathrm{p}=0 \cdot 15)$, no clear pattern by regions, although differences were apparent $\left(\chi_{12}^{2}=50.0\right.$, $\mathrm{p}<0.01$ ), and no evidence of changes over time $\left(\chi_{4}^{2}=1 \cdot 1, p=0 \cdot 90\right)$.

\section{Discussion}

Registration of more than 400 participants and 200 centres was beyond our initial expectation. Although numbers of unnotified grafts remain unclear, demand for banked tissue, and hence notification, has increased sharply, especially from surgeons who reported fewer grafts in 1988. It is plausible that ready availability of donor tissue supplied through CTS eye banks (Bristol and Manchester) has encouraged more ophthalmologists to transplant corneas routinely. This view is strengthened by finding that, although numbers of reports increased more from surgeons performing fewer grafts, proportions of risk factors remained essentially unchanged over time. Local, scheduled operations are more convenient for patients, but potential influences of this trend on graft outcome remain to be examined.

Differences in patient characteristics between individual centres with particular specialisation is not surprising. However, it may have been expected that such differences would even out on a regional scale. We found regional variation not only by administrative factors such as reported transplant rates, but also by a major risk factor: numbers of previous grafts in the operated eye. The extent of such differences, even when unexpected, underlines the complex inter- 


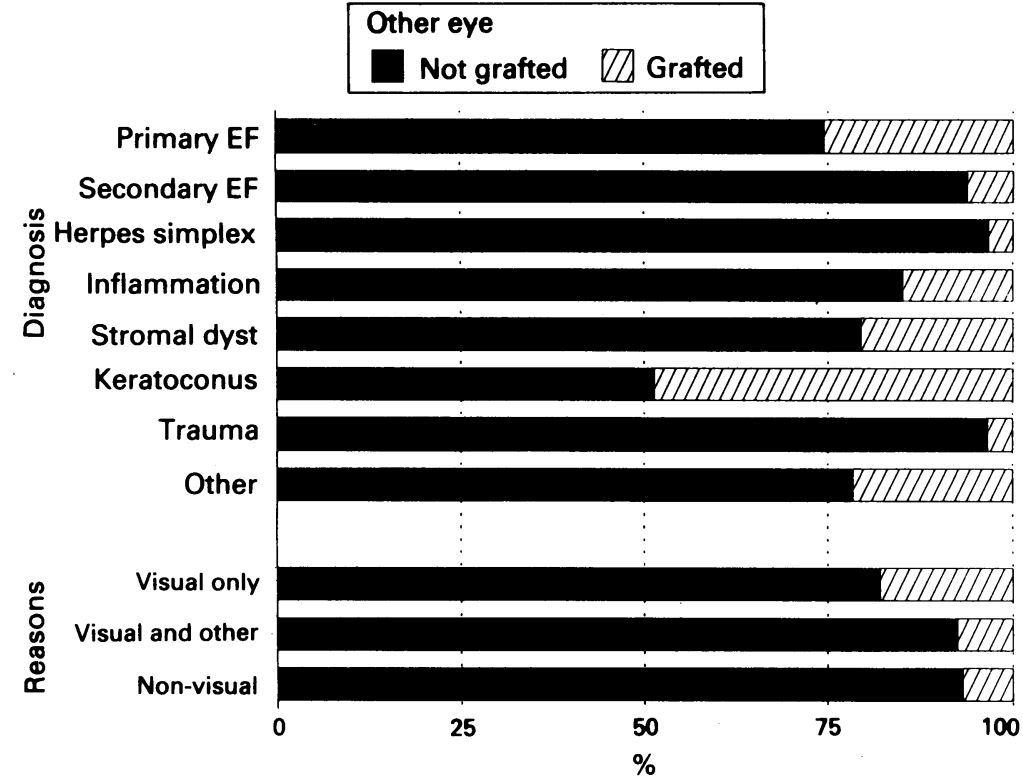

Figure 8 Other eye status by diagnosis and reasons for grafting. $E F=$ endothelial failure; Dyst $=$ dystrophy. dependence of risk factors, and emphasises the need for multifactorial analyses of graft outcome.

Response rates have a major influence on study credibility. The four pages of the transplant reporting form, and three pages for each subsequent form, may have discouraged some from participation. It is noteworthy that surgeons reporting more than 50 transplants completed proportionately more forms $(83 \%$ versus $66 \%)$, presumably because of specialist interest. Their patients' characteristics also differed, as might be expected to result through referral from less specialised centres. This may have resulted in overestimates of the prevalence of risk factors. However, series published by individual centres are more prone to bias from specialist interest or local practice. ${ }^{3}$ Analyses of graft outcome should not be unduly biased since response rates to follow up forms did not differ by recipient characteristics.
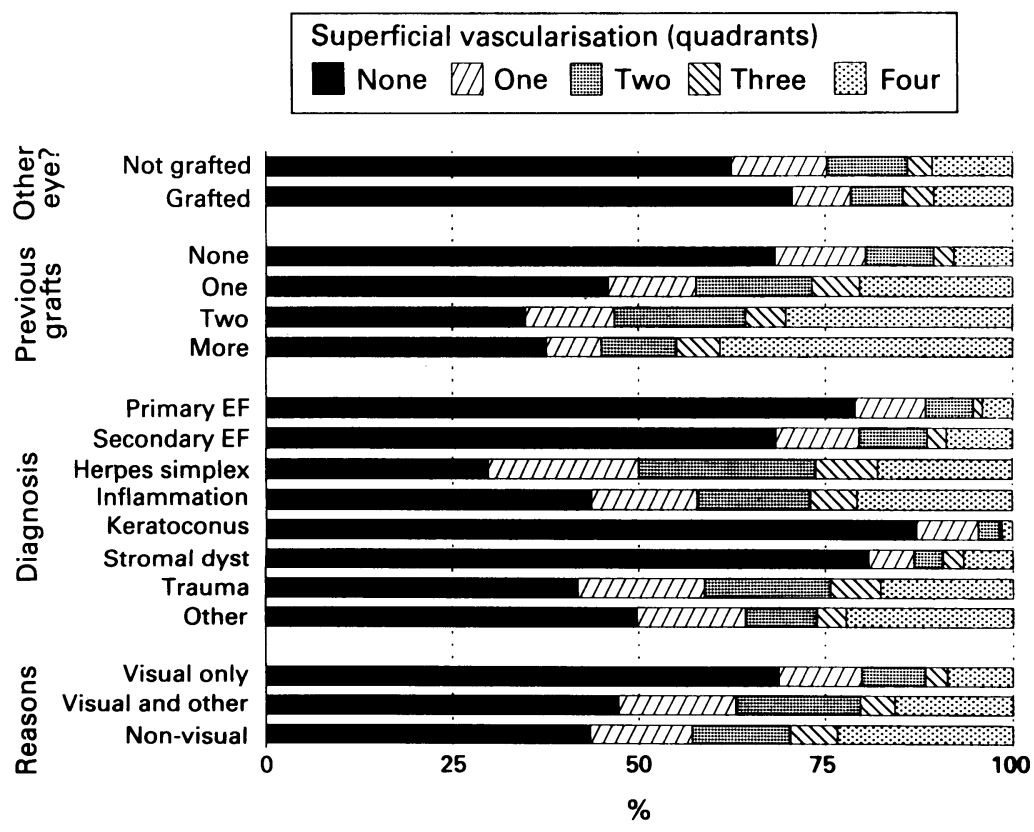

Figure 9 Superficial vascularisation by other eye status, previous grafts, diagnosis, and reasons for grafting. $E F=$ endothelial failure; Dyst=dystrophy.
One in four recipients had suffered secondary endothelial failure. Although it is thought likely that numbers of such patients following cataract extraction will decrease, there was no evidence of this during CTFS. It is also possible that, with the growth in refractive surgical techniques for the treatment of myopia, secondary endothelial decompensation will be a continuing indication.

Only 207 keratoplasties $(6.5 \%)$ were reported to have no visual motive. This supports the view that information about factors affecting visual performance is essential. CTFS now constitutes a detailed national database of over 3000 corneal transplants. Analyses currently under way of graft survival, postoperative complications, rejection episodes, visual acuity, and astigmatism should therefore provide informative guides to future practice.

CTFS is funded by the Department of Health 'Research and Development' Division. We thank Mr Arthur D McG Steele, of Moorfields Eye Hospital, for help in phrasing questions, staff of CTS eye banks for support received throughout, and Mrs Kirsty French for tireless data management. Most importantly, we thank our collaborating surgeons (appendix) and their patients.

1 Bradley BA. Corneal supply in the United Kingdom. Trans Ophthalmol Soc UK 1986; 105: 397-400.

2 Armitage WJ, Moss SJ, Easty DL, Bradley BA. Supply of corneal tissue in the United Kingdom. Br F Ophthalmol 1990 74: 685-7.

3 Morris RJ, Bates AK. Changing indications for keratoplasty. Eye 1989; 3: 455-9.

\section{Appendix}

COLLABORATING SURGEONS

Absolon MJ, Adams AD, Adhikary HP, Aggarwal JL, Aggarwal $\mathrm{R}$, Aggerwal SP, Ahmad N, Ainley RG, Akingbehin AO Alexander W, Allchin RW, Allen ED, Alvarez E, Andrew NC, Anson A, Armstrong S, Arnott EJ, Astbury NJ, Atkins AD, Atkinson AJ, Atta HR, Auplish RN, Awdry PA, Baines PS, Barber K, Beck L, Beckingsale AB, Bedford G, Benjamin L, Bhalerao VR, Bhargava SK, Bhattacharyya S, Black PD, Boase DL, Bolger J, Boohdoo MG, Booth-Mason SA, Bosanquet RC, Bowen DI, Brazier DJ, Bron AJ, Brown AC, Brown IAR, Brown NE, Brown RD, Buckley RJ, Burgess SEP, Butler L, Butler RE, Calder IG, Calver D, Canning CR, Cappin JM, Casey TA, Castillo AA, Catford GV, Chadwick AJ, Chandra KP, Chatterjee S, Chawla JC, Cheng H, Chesterton J, Chignell AH, Choudhuri SK, Clements DB, Clerkin LG, Coakes RL, Cobb ML, Coddington WG, Cole MD, Coleiro JA, Collum LMT, Common JDA,
Condon PI, Condon RW, Cook SD, Cory C, Cottrell DG, Cox SN, Condon PI, Condon RW, Cook SD, Cory C, Cottrell DG, Cox SN, Cullen JF, Dabbs TR, Dalgleish R, Dallas NL, Dang MS, Daniel R, Dart JKG, Darvell RHJ, Das SN, Datta SK, Davidson SL,
Davies PD, Davies TG, De S, De Alwis TV, Deady JP, Desai SP, Docherty P, Dodd CL, Doig WM, Doran R, Dorrell ED, Downes RN, Duguid IM, Dunne JA, Duvall-Young J, Eagling E, Easty DL, Edwards RS, Elliot A, Ellis RP, Enoch BE, Etchells D Eustace P, Evans K, Falcon MG, Fawzi HH, Feddo FIK, Fenton PJ, Fetherston TJ, Ficker LA, Fielder AR, Finlay RD, Fisher FF, Fison P, Fitzmaurice DJ, Fleck BW, Ffooks OO, Freedman A, Galloway NR, Garston JB, Gibson RA, Gillespie I, Gillie RF, Goble R, Gopal KSS, Govan JAA, Graham CM, Grayson MC, Green FD, Griffith TP, Gurney PWV, Hagan MC, Haining WM, Hall RD, Halliday B, Handscombe MC, Harding SP, Harfitt R, Harper HF, Harrison RJ, Hasan M, Hashmi MS, Haslam JD, Haworth SM, Highman VN , Hillman JS, Holding P, Holroyd B, Holt-Wilson AD, Hopkins D, Howe J, Hubbard IH, Hudson JM, Huggan JD, Hughes J, Hunter JW, Hunter P, Hutchinson C, Hyde G, Idrees M, Ingram D, Jackson LS, Jacob JSH, Jacobs PMd James PML, Jay J, Jeffrey MN, Johnson PB, Jones CA PM, James PML, Jay J, Jeffrey MN, Johnson PB, Jones CA, Kaka SH, Kamaluddin SM, Karseras AG, Kaushal K, Kaushik N, Keightley SJ, Kemp EG, Kempster RC, Kennerley Bankes JL, Kerr Muir MG, Kervick G, Kesby BR, Khalek MN, Khan MY, Kidd MN, Kinnear PE, Kirby GR, Knight-Jones D, Knowlden J, Kritzinger EE, Kumar RD, Kyle GM, Kyle PM, Lakhanpal GK, Lamb RJ, Lavery $\mathrm{FL}$, Learmont D Leatherbarrow B, Leighton DA, Leonard JK, Longstaff S, Lyall M, Lyne AJ, Lytton A, MacDonald M, MacEwen CJ, MacFarlene AI, MacKillop A, Mackenzie AD, Magauran D, Mandal AK, Manson N, Marmion VMJ, Marsh IB, Marsh RJ, Martin JP, Mathalone MBR, Mathur AK, McAlister J, McConnell JMS, McDonnell PJ, McGettrick P, McGhee CMJ, McGrand JC McGregor-Drummond P, McKelvey JAW, McLeod BK, Mcgill II, Mehta HK, Michell D, Migdal C, Miller JT, Mills KB, Mills PV, Milson JE, Mishra AK, Mohammad KKF, Mohan-Roberts V, Moore AT, Morgan LH, Morgan SJ, Morrice GD, Morrision V, Moore AT, Morgan LH, Morgan SJ, Morrice GD, Morrison AM, Moss J, Munton CGF, Murphy AG, Murray SB, Nairne JH, Noble PJ, O'Driscoll TG, O'Keefe M, O'Neill E, O'Rourke PJ, 
Owen DA, Packard R, Palmer CA, Paran PN, Patterson A, Paul MR, Pearce J, Peckar CO, Percival SPB, Phelps-Brown N, Phillips CI, Pickering A, Pieris SJP, Porteous ID, Porter GP, Porter R, Porter S, Powell R, Prasher KK, Price NC, Price NJ, Pyne JR, Quinlan M, Rahman M, Ramsell TG, Ramsey J, Rees WE, Rennie AGR, Rennie IC, Rerrie JD, Rich WJC, Richards AB, Richards FH, Richardson J, Richer RG, Ridgway AEA, Ridley R, Rizk S, Robertson IR, Roper-Hall MJ, Rosen ES, Rostron C, Roxburgh ST, Rubasingham AF, Rumble JA, Sandford-Smith J, Sarkies NJC, Schulenburgh WE, Scott JD, Sellers JI, Setna PH, Shan S, Sharma SK, Sharp CI, Shaw PA Shepherd WFI, Shilling JS, Sikka OPS, Simpson E, Simpson W,
Singh L, Siva-Yoham IS, Smail JM, Smerdon D, Sollom AW, Spolton M, Stannard KP, Strachan IM, Strong JD, Sturrock G Sullivan SC, Sutton GA, Talbot JF, Tandon MK, Tattersfield JF, Taylor PT, Thaller VT, Thompson G, Thompson SM, Thomsit J, Tolia JJ, Toor KS, Townsend C, Travers JP, Trimble RB Tudor JC, Tullo AB, Tutton MK, Twomey JM, Vernon SA, Vernon-Smith VHS, Viswanathan B, Vivian T, Walker CB, Walshaw NWD, Wang MK, Watson AP, Watson DM, Watson PG, Watts MT, Weatherill JR, Welham R, While A, Whitwell J, Williams R, Williamson J, Willshaw HE, Wilson RS, Wilson W, Wishart PK, Wood CM, Woodhouse DF, Woodruff GHA Worstmann T, Wykes WN, Young JDH, Zaidi AA.

\section{History of ophthalmology}

\section{On manual dexterity}

Eye surgeons need a degree of manual dexterity, and by and large this occurs by a process of natural selection. For some reason this wasn't so in Prague in the 1940s, as shown by the following revealing quote from Professor Loewenstein's lecture at the Tennent Institute of Ophthalmology; 'Having seen many young men starting ophthalmology, I am amazed by the surprising fact that our profession (which by general consent requires at least moderate skill and dexterity) appears in Czechoslovakia to attract like a magnet the most adexterous people. One cannot explain this dark riddle of nature, but is it wrong to exclude any person on the grounds that he is handless?' After discussion, the lecturer concluded that ophthalmology must 'examine the beginner, admit the gifted, and refuse the less able.' A debatable point!

Loewenstein's own teacher Elschnig fostered ambidexterity by insisting that pupils operated on the left eye with the right hand, and vice versa. There must have been times when this affected the outcome of more delicate operations. Believing that 'all finger work aided eye work,' he had his trainees 'exercising the fingers like a pianist' and cutting minute pieces of cotton wool with De Wecker's instrument (instead of having a rest and a coffee) between cases.

H B Stallard, author of the famous surgical text, also considered the question of dexterity, but held the opinion that one's natural talents could be considerably improved by practice. He advocated cutting individual hairs off the opposite forearm with scissors, and though this would result in a peculiar appearance in the hirsute, it undoubtedly improves dexterity. $\mathrm{He}$ also suggested that removing foreign bodies from a dead animal's cornea was beneficial to the budding eye surgeon, but unfortunately gave no hints as to the source of the animals.

Even when dexterity is accomplished, it may depend on circumstance, varying inversely with the size of the audience and the importance of the operation. A famous ophthalmologist in the 1930s was aware of the deleterious effect of the 'gallery' on his manual skills, and used to dread important cases. He adopted the solution of arriving fifteen minutes before the appointed time, in the hope of rushing through the procedure before the eminents arrived.

Modern literature again mentions the use of dead cow and sheep eyes in training, and this may become more widespread. (But with increasingly tight budgets, who will pay the butcher's fee?)

FIONA ROMAN

Gayer Morgan $O$. The education of an ophthalmic surgeon. BrF Ophthalmol 1942; 26: 183-6.

Loewenstein A. The education of an ophthalmic surgeon. 